\title{
CONCEPTUAL FRAMEWORK OF MULTI-STRUCTURAL LANGUAGES IN A COMPARATIVE ASPECT (THE RUSSIAN AND ENGLISH LANGUAGE AREAS)
}

\author{
Tatyana N. Pavlova ${ }^{1 *}$, Evgenia A. Grigoreva ${ }^{2}$, Mariia E. Petukhova ${ }^{3}$ \\ Ekaterina A. Kozhemyakova ${ }^{4}$, Irina A. Simulina ${ }^{5}$, Gennadiy E. Kornilov ${ }^{6}$ \\ ${ }^{1}$ Assoc. Prof., Chuvash State University, RUSSIA, antat12@mail.ru \\ ${ }^{2}$ Assoc. Prof., Chuvash State University, RUSSIA, geva1979@yandex.ru \\ ${ }^{3}$ Assoc. Prof., Chuvash State University, RUSSIA, petuhovame@yandex.ru \\ ${ }^{4}$ Assoc. Prof., Chuvash State University, RUSSIA, ekozhemyakova@yandex.ru \\ ${ }^{5}$ Senior Lect., Chuvash State University, RUSSIA, arin7.7@yandex.ru \\ ${ }^{6}$ Prof. Dr., Chuvash State University, RUSSIA, gennkorn@ramblerl.ru \\ ${ }^{*}$ Corresponding Author
}

\begin{abstract}
The present study focuses on the comparative description of the concepts of the unreal world in Russian and English. The research of mythological and religious ideas about the unreal world which is specific to speakers of two languages has been taken to study in ethnography, folkloristics and culturology. At the same time, the linguistic study of this phenomenon was sporadic, both in the conceptology and in comparison of multi-structural languages. The above-mentioned determines the relevance of this srudy, which attempts to define the nature of the concepts of "angel" as a subject of the unreal world, which are peculiar to native

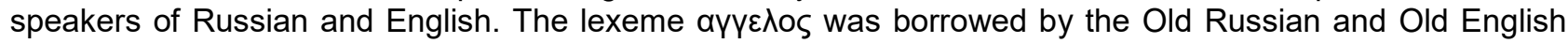
languages areas as part of the cult vocabulary. Originally, the functioning of the mentioned lexeme in both languages was limited to the Holy Scripture, in the texts of which this lexical unit was used in two main meanings: ангел 1 / angel 1 'according to religious ideas, a supernatural disembodied creature, a good spirit' and ангел 2 / angel 2'according to religious ideas, a supernatural disembodied creature, an evil spirit'. These lexical-semantic variants are an example of a quite rare linguistic phenomenon of enantiosemy - a type of antonymy, when as the antonyms act not separate lexical units, but lexical-semantic variants of the same word. The lexical compatibility of these lexical-semantic variants contributes to their distinction in the texts of Holy Scripture. In addition, in the Russian texts of the Holy Scripture, the lexeme angel has another lexicalsemantic variant, which serves to denote John the Baptist. Further based on values of the lехете ангел 1 / angel 1 the new lexical-semantic variants were developed in both languages. They were semantically identical and differentiated in meaning. The structural comparison of the intra-word semantic paradigm of the lexemes ангел / angel clearly illustrates the thesis that the measure of polysemy of the same word is distinct in different languages. The linguistic and conceptual analysis of the imagery of the language of the Russian classical poetry made it possible to identify some of the motivational features underlying the name of the angel as a subject of the unreal world, and therefore to reconstruct the approach of human thought to this phenomenon, as it was when the word was created.
\end{abstract}

Keywords: lexical-semantic variant, synonymy, enantiosemy, concept, conceptual framework, multistructural languages. 


\section{INTRODUCTION}

In modern linguistics scientist mainly focus on how a language (the object of knowledge) is related to its native speaker (the subject of knowledge), in other words to a person. This view of a language was formed within the framework of the anthropocentric paradigm and was developed in the works of Russian and foreign linguists, such as Yu. S. Stepanova, E. S. Kubryakova, N. D. Arutyunova, S. G. Vorkachev, V. Z. Demyankova, A. Wierzbicka, J. Lakoff, C. Fillmore and others. The study of the language and culture of different peoples and the solution of the issue of the interaction of these two phenomena have led modern linguists to the statement that "a language is closely related to its culture: it intergrows and develops within the culture" (Maslova, 2001, p. 9).

The present study focuses on the comparative description of the concepts of the unreal world in Russian and English. The research of mythological and religious ideas about the unreal world (which is specific to speakers of two languages) has been taken to study in ethnography, folkloristics and culturology. At the same time, the linguistic study of this phenomenon was sporadic both in the conceptology and in comparison, of multi-structural languages. The above-mentioned determines the relevance of this study, the subject of which is the connection of the lexical units ангел / angel with the spiritual culture of Russian and English speakers.

The purpose of the research is the comparative analysis of national concepts of the unreal world, the identification of their specifics and investigation of the role of these concepts in the linguacultural context of ethnic groups.

The goal of the research requires studying the corpus of lexical units that represent the concepts, taking a look at the intra-linguistic synonymous relations of lexemes included in the mentioned concept, establishing the degree of interlinguistic equivalence of the indicated units (complete, partial, non-equivalent) and indicating the integral and differential features of the concepts of the unreal world in these languages.

The multidimensionality of the study determines the use of a complex of methods. Due to the fact that the main object of study was the concepts of multi-structural languages, the main method was the conceptual analysis. The selection of lexical units was conducted by using the continuous sampling method out of defining dictionaries of various types and bilingual dictionaries. The study of the semantic structure of the formations we are interested in led to the use of the component analysis method. The comparison of units of multi-structural languages was conducted by using the comparative method.

The basis for the study was the content of defining dictionaries of the Russian and English languages. Also, we used data documented in the Dictionary of the poetic language, as well as the texts of the New Testament in Russian and English as primary sources for this research article.

\section{FUNCTIONAL FEATURES OF THE LEXEMES AHГEת / ANGEL IN RUSSIAN AND ENGLISH}

It is common knowledge that lexical meaning of a word is determined by several factors, among which a denotatum plays an important role. However, there are examples in any language where there is no subject, but a concept and a word exist. B. Yu. Norman calls these particular examples "phantoms" (Norman, 2004, p. 160), Yu. S. Maslov thinks that they can be defined as "words related to imaginary denotata and their designates (representations of the denotatum) are false concepts that arose at some stage of the cultural development and were discarded later" (Maslov, 1987, p. 92). A. Ufimtseva noted that "among the lexemes of any language one can identify such units whose significates are the concepts of unreal objects, constructions of a human thought, and they fail to correspond with any real objects" (Ufimtseva, 1986, p. 107). This group includes the names of the creatures produced by human imagination: a centaur, a mermaid and a griffin. In our opinion, this group should also include the lexeme "angel', whose lexical-semantic variants contain the seme "spirit", cf: lexical-semantic variant angel 1 'in Jewish, Christian and Muslim mythology: a supernatural disembodied creature, God's agent who protects people; a good spirit' (Bolshoi, 2001, p. 39), lexical-semantic variant angel 2 'in Jewish, Christian and Muslim mythology:a supernatural disembodied creature, an evil spirit; a fallen angel, a devil, Satan' (this lexical-semantic variant has a limited scope of usage, since it is represented only in the texts of the Old and New Testaments).

The ideas of these imaginary objects slightly vary from an individual to an individual. Thus, despite the universal nature of cognitive and thought processes, the cognition of the environment among different peoples has a versatile depth, which leads to differences in the conceptual picture of the world, reflected in a language. In this work we attempted to determine the nature of the notion "angel" as a subject of the unreal 
world, typical for Russian and English native speakers.

Throughout history, the Russian language has constantly contacted with other languages and cultures. Whereby, the vocabulary of the Russian language has been enriched with foreign words from other countries. The English language has also been influenced by many other cultures and languages. Undoubtedly, the Greek world had a great influence on the culture and language of the Russian and English speakers, which became the source of the new Christian faith. Along with borrowed religious ideas, the grecisms became a part of the composition of lexical systems of both languages. Comparing the lexical layers of the Russian and English religious vocabulary, we can say that the specific religious terminology of both language systems has a conspicuous borrowed character. Various concepts are interpreted using Greek words (that are graphically and phonetically assimilated in the Russian and English languages): ангел -angel, архангел - archangel, Апокалипсис -Apocalypses, апостол - apostle, дьявол - devil, евангелист evangelist and others. According to E. V. Kuznetsova's the classification of borrowed words, this group of lexemes must be classified as so-called internationalisms ("lexical units that exist in at least three languages and are not related to the origin and do not belong to the same area") (Kuznetsova, 1989, p. 144).

As it is well known, the lexeme ayyenos (God's agent in Greek) was borrowed by the Old Russian and Old English language areas as a part of the cult vocabulary. Primarily, the functioning of the mentioned lexemes was limited to the Holy Scriptures, in the texts of which the indicated lexical unit was used in two main meanings: ангел 1 / angel 1 'religious ideas, a supernatural disembodied creature, a good spirit' and ангел 2 / angel 2 'religious ideas, a supernatural disembodied creature, an evil spirit'. The synonyms of the first lexical-semantic variant (hereinafter referred to as the LSV) are the lexemes архангел (archangel), серафим (seraph), херувим (cherub), the second LSV has paradigmatic connections with the units бec (devil 2), злой дух (evil spirit; wicked spirit), нечистый дух (unclean spirit), нечистый дух бесовский (spirit of an unclean devil).

Russian and English speakers proposed Christian ideas, according to which good spirits were created by God and served God (Matt. 22. 30; 25. 31); they were his agents to people; his messengers (Luke 1: 11-20); they could cure people (John 5: 4); they served as disciples and church preachers (Matt. 11: 10). However, the ideas about the mentioned objects of the unreal world (which are identical at the conceptual level of the two languages) have different language implementation, which is related to the features of the morphological structure of the compared languages, as well as to the distinction in the heritage of lexemes' graphic representation (which belongs to the cult vocabulary in the Russian and English cultures). Indeed, according to the Russian graphic tradition, all nouns, adjectives, personal and possessive pronouns that are used to denote God, Jesus Christ, the Virgin Mary or define these proper nouns in the texts of Holy Scripture, must be written in capital letters, cf.: "Jesus answered: "If I glorify Myself, My glory is nothing. It is My Father that glorifies Me, HE who you say is YOUR God. And you have not known Him; but I know Him (John 8: 54, 55). In the New Testament (in the English version), this graphic representation rule of words applies only to similar nouns, cf.: Jesus replied, "If I glorify myself, my glory means nothing. My Father, whom you claim as your God, is the one who glorifies me. Though you do not know him, I know him (John. 8. $54,55)$. It is also worth mentioning that the LSV ангел $1 /$ angel 1 is always capitalized in the Russian translation ("When the Angels had left them and gone into heaven, the shepherds said to one another: let's go to Bethlehem and see" (Luke 2. 5.)) and lowercased in English ("When the angels had left them and gone into heaven the shepherds said to one another Let s go to Bethlehem and see this thing» (Luke 2. 5.)).

The LSV ангел 2 / angel 2 is rarely used in the texts of the New Testament where the synonymous lexical units бес (devil 2), злой дух (evil spirit; wicked spirit) and нечистый дух (unclean spirit) are frequently used. The noted LSV is used only if it is necessary to update the storyline of the origin of the devil, who was once an angel who rebelled against God and was cast into hell. Furthermore, this biblical story is indicated by some collocations with the general meaning of 'evil spirit' documented in defining dictionaries: падший ангел (the fallen angel), ангел смерти (the angel of the death), ангел тьмы, evil angel, as well as the lexeme Люuиqpep (Lucifer), which is used to denote Satan (cf.: Lucifer 'Satan, esp.as the leader of the angels revolt before his fall'). Therefore, there are two opposed meanings of the LSV of the same word in texts of the New Testament in Russian and English. In our opinion, the mentioned LSV is an example of a rather rare linguistic phenomenon "enantiosemy" - a type of antonymy where the antonyms are not separate lexical units, but lexical-semantic variants of the same word.

The lexical compatibility of these LSV data contributes to their distinction in the texts of the Holy Scripture. As for the LSV angel 1 / angel 1 are characteristic epithets that indicate the divine origin of the object of nomination - Ангел Божий (the angel of God), Ангел Господень (the angel of the Lord), Ангел Мой (ту ange), Ангел Свой (his angel), His chosenness - Ангел Святой (angel( the specified epithet is omitted in 
the English variant)), место обитания - Ангелы небесные (angels in heaven), Ангелы с небес (angels from heaven). For example, "... but are like God's angels in heaven." (Matt. 22: 30). The sememe ангел 2 I angel 2 is implemented in the combinations ангел бездны (the angel from the Abyss), ангелы, не сохранившие своего достоинства (the angels who did not keep their position of authority), ангелы согрешившие (angels when they sinned), диавол и ангелы его (the devil and his angels): "For if God didn't spare angels when they sinned, but cast them down to Tartarus, and committed them to pits of darkness, to be reserved for judgment" (2 Peter. 2. 4.).

Moreover, in the Russian texts of the Holy Scripture, the lexeme angel has another LSV, which is used to define John the Baptist and is employed in the following contexts: "This is the One about whom it is written: "'I will send My messenger ahead of You, who will prepare Your way before You" (Luke 7: 27), "I will send My Messenger, who will prepare the way before Me. Then suddenly the Lord you are seeking will come to His Temple; the Messenger of the covenant, Whom you desire, will come, "says the LORD Almighty." (Malachi. 3. 1). In similar English contexts, this version of the lexeme angel is replaced by the word 'messenger', cf.: "This is the one about whom it is written I will send my messenger ahead of you, who will prepare your way before you (Luke 7. 27), "See, I will send my messenger, who will prepare the way before me" (Malachi 3. 1). This disparity in translations is related to the fact that in the Russian text the word angel is used in its original meaning, which appeared in the Greek language as a "messenger', and in the English text it is replaced by the English lexeme with the same semantics. The representation of John the Baptist as an ideal ascetic and the emphasis on the monastic side of his image is characteristics of the Russian Orthodox tradition. Naming him an angel in the texts of the New Testament leads to the fact that the cult vocabulary of Russian Orthodoxy appears collocations denoting monasticism and monastics, which include derivatives of the named lexeme: angelic image 'monasticism', great angel 'schema', to angel 'be a monk, take vows of schema' (Dahl, 1978, p. 16). The portmanteau of the representation of John the Baptist as a messenger and as an angel, which is characteristic of the Orthodox worldview, is confirmed by iconographic material: since the XVI century the iconographic type "John the Baptist, an angel of the desert" has become very popular in the Russian iconography, giving it wide angelic wings (Myths, 1994, p. 552).

The more revealing is the history of further semantic development of the mentioned internationalisms in the designated multi-structural languages. It must be noted that the LSV of ангел 2 / angel 2 has the same limited functioning in the modern Russian and English texts of the Holy Scripture. Based on the LSV ангел 1 / angel 1, the new LSV was developed in two languages, semantically identical and differentiated in meaning. The structural comparison of the intra-word semantic paradigm of these lexemes clearly illustrates the thesis that the measure of polysemy of the same word is distinct in different languages. The nonequivalent English lexical-semantic variants appeared only as a result of the implementation of the "potential" semes of the LSV of angel 1, which were not previously interpreted as essential, but were later updated in the secondary meanings of this lexical unit. These LSV are divided into two groups, as they can denote either a person or an object. Thus, there was an actualization of the seme 'ambassador' in the version of angel 5, poet, 'agent, messenger' which was originally embedded in the semantics of the variant angel ' good spirit', cf.: angel 'in Christian belief messenger from God shown in pictures as a human being in white with wings' (Oxford, 1982, p. 33). The variants of angel 6 coll. 'organizer, sponsor' and angel 7 theater. 'patron, supporter' are almost identical in meaning, because each of them has the archiseme 'one who provides assistance'. They implement the peripheral component 'guardian, patron' of the variant angel 1 (ангел-хранитель, guardian angel) and differ from each other only in a set of distinct semes and the sphere of functioning. The transfer of meaning and presence of the angel 9 LAN radio coll. 'radar echo from an indistinguishable reflection' occurred due to coming to the fore of the seme 'disembodied, supernatural being', as well as the implementation of Christian ideas that angels are spirits and remain indistinguishable to the human eye. However, despite the postulate that good spirits are invisible, they were depicted as beautiful winged young men dressed in white clothes. Such representations were actualized in the meaning of the variant angel 10, which used to denote the upper flying sail in the jargon of English sailors (the seme 'white', 'winged'). The lexical-semantic version of angel 8 'gold coin' appeared as a result of extralinguistic factors. The coin has got this name because it had an image of an angel on it.

\section{FUNCTIONAL FEATURES OF THE LEXEMES AHГEת / ANGEL IN RUSSIAN AND ENGLISH THE FIGURATIVE POTENTIAL OF THE LEXEME ANGEL IN RUSSIAN POETRY OF THE XVIII-XX CENTURIES}

As a source of conceptual information, we also selected Russian lyric texts from the era of the formation of Russian lyric poetry at the end of the XVIII century to the poetry of the first third of the XX century. The basis for the linguistic and conceptual analysis was the figurative means of the poetic language - poetic 
nominations, that is, "combinations of words and a word that have a special aesthetic meaning in poetry, a specific semantic and expressive load" (Dictionary, 2004, p. 7). The language analysis of poetic texts has shown that the lexeme ангел is included as one of the components or as an object for the nomination in the following units of the language of poetry:

1) descriptive and metaphorical combinations (the serene angel, the angel of peace - about silence, the angel of death, the angel of death and oblivion, the angel of severe God, the angel of extermination - about death, the angel of evil -about fate);

2) periphrastic combinations (a messenger of God, a messenger of heaven, a messenger of paradise - about an angel, a guest of the heaven, a visitant, a guest of the heaven's side - about an angel, a messenger of grace, a messenger of God's Council, a winged messenger - about an angel). Moreover, the first type of these units is the most frequent one. Therefore, combination periphrases indicate the most significant features of the object of the nomination and its characteristic features. As periphrasis serve the word combinations with the supporting agents spirit, son, guest, tenant, resident, messenger, agent, ambassador, wanderer, the disseminators of which indicate a number of properties of the designated object: appearance (beautiful son of heaven, bright guest of the heaven's side, winged messenger), character features (pure spirit, full spirit of charity, sinless spirits), place of stay (spirit of Eden, spirits of the lofty world, messenger of paradise, guest of heaven, resident of heaven, tenant of heaven, wanderer of heaven), main functions (messenger of God's Council, messenger of God, host of God, servants of the Lord, Lord of the door of Eden), for example: The fall of man has issued out and the messenger of heaven praising speechlessly has opened the way to the lost soul (Klyuyev, I remember the early mass...). Additionally, in poetic texts the lexeme angel is often concretized with the help of epithets that define this object and emphasize some characteristic property or quality in it: pale angel, blue-eyed (a pale blue-eyed angel, you walk in the darkness of the alley), a pale-faced angel of the Night (Silent shadows string out and go through the northern portal but the pale-faced angel of the Night has not yet read the cathisma), a light-winged angel (A pale angel, a light-winged angel, released to us on earth!), a beautiful and winged angel (Let the beautiful and winged angel of sleep come and let it take you to another life!), a tired angel (pale angel that was tired of too bright light of the day).

The descriptive and metaphorical combinations with the component angel, therefore, serve to denominate objects and phenomena of the surrounding world or describe the spiritual sphere of the human personality. According to the most ancient animistic representations, every object of animate and inanimate nature has a soul or a spirit protecting it. These representations are fully reflected in these metaphors, which describe natural phenomena (storm - the stormy angel, rain - the rain angel), seasons of the year (spring - the spring angel), time periods (day - the golden-curled angel of the day, night - the pale-faced angel of the Night, twilight - the warm angel), astronomical bodies (moon - as an angel among the outcasts, stars - the angel of stars). In Russian poetic texts the angels are spirits related to a variety of natural forces. They control, manage and watch the rain (I watch the rain angel fertilize the naked earth (Bryusov, the Cheerful call of spring greenery...)) and the storm (What are you looking forward to? You want to read if there's any news? Are you waiting for a stormy angel? (Blok, We are forgotten alone on earth..)). In the metaphorical combinations of the angel of spring and the golden-curled angel of the day we find the representation of an angel as a young, beautiful, golden-haired creature, whose clothes seem to consist of light and lightness, speed and brilliance. This makes it possible to bring together such seemingly different concepts as "day" and "angel", whose essential feature is the connection with light, cf.: A golden-curled angel of the day turns into the night fairy, but she leaves ringing (Blok, Golden-curled angel of the day..); Languishes the bygone day like a seraph in pictures of Botticelli, scattering a lock of gold on the neck of the silent cello (Annensky, Longing for return). It is also worth noting that the metaphor day - light, day- shine is quite frequent in Russian poetry and is implemented in numerous poems, for example: The Holy night has risen to the sky and the pleasant kind day, like a golden veil, has twisted a veil thrown over the abyss. (Tyutchev, the Holy night has risen in the sky.); Over the mysterious world of spirits, over this nameless abyss a golden-woven veil is thrown by the high will of the gods. This day is resplendent veil (Tyutchev, Day and Night); Days become shorter and shorter and their silvery overflow (Narbut, Autumn). Furthermore, the representation of an angel as a bright celestial spirit is implemented in metaphorical combinations that are used to describe the moon and stars. These astronomical bodies are likened to angels in the poetic texts of $\mathrm{M}$. Yu. Lermontov and A. I. Odoevsky: The silvery moon like an angel among the outcasts between the clouds was wandering, throwing a ray at you (Lermontov, Lean towards me, handsome young...); and the angel of bright stars controls the stern (Odoevsky, Moon).

Another group of metaphors with the component the angel describes the emotional state - sadness, happiness, hope, which are represented as a result of the impact of outside forces on it: sadness -the sad 
angel (And only in the bitter hour of offense the sad angel became visible... (Blok, Where given in long halls..)), happiness - the angel of happiness (And an angel of happiness flew over us quietly!..(Ratgauz, Lowering his gaze)), tears - the angel of tears (When you, the angel of tears, touch with wings the eyes of the mortal man the fog lifts with tears (Tyutchev, Tears)), silence - the blessed silence angel (Make it keep silent, the blessed silence angel ... (Bryusov, Prayer)), hope - the sweet angel of hope (And with the sweet angel of hope he goes and not coming yet, $\mathrm{He}$ is happy with waiting for what is waiting for him on the promised pier! (Zhukovsky, November, winter's ambassador)). The perception of feelings and emotions as a a kind of substance (that exists outside of a man and can overtake him) is also a fairly ancient relic of animism and it has its linguistic implementation not only in the indicated tropes, but also in the actual Russian phraseological units (see, boredom overtakes, boredom comes upon, boredom takes hold, boredom overcomes; sadness overtakes, sadness creeps into the heart, sadness lives in the heart / in the soul) and in combinations that have an established character (demon of evil, demon of discord, demon of lies, demon of doubt, demon of national hatred, spirit of contradiction). Curiously, the metaphors, that are used in poetry to describe negative emotions, are very often composed of lexical units with the archiseme 'spirit': sadness - gloomy genius of sadness (A. S. Pushkin), demon that causes to fall on (E. A. Baratynsky), sad spirit (A. A. Blok); sadness - vengeful fairy (K. Fofanov); envy - demon of envy (V. A. Zhukovsky), demon of envy and revenge (A. I. Polezhaev); jealousy - jealous demon (D. p. oznobishin); doubt - demon of doubt (Ya. P. Polonsky), the heavy spirit of doubt (A. N. Apukhtin), the poisonous spirit of doubt (I. I. GoltzMiller); malice - the spirit of malice (I. I. Chemnitzer), the heavy wing of the spirit of malice (A. A. Fet), the evil spirit (A. K. Tolstoy). Therefore, one of the techniques of describing emotions in Russian poetry is a personifying metaphor, which most often includes the lexemes angel, spirit and demon.

As a result, the study of the functioning features of the internationalisms ангел / ange/ suggests that the lexical systems of two languages assimilate the same borrowed word in different ways. It has to do with the peculiarities of language systems themselves, for example, with a predominance of lexical-semantic methods of forming words in the English language, where more frequently borrowed lexemes are used, as well as the limited functioning of the lexeme angel in the Russian language and with greater productivity of morphological ways of word formation in the Russian derivational system. Furthermore, the linguistic and conceptual analysis of the imagery of the language of the Russian classical poetry makes it possible to identify some of the motivational features underlying the name of an angel as a subject of the unreal world and to combine them to reconstruct the approach of "human thought to this phenomenon, as it was when the word was created"(Maslov, 1987, p. 57).

\section{REFERENCE LIST}

Big explanatory dictionary of Russian language (2001) (Russ. ed.: S. A. Kuznetsov. Saint Petersburg) (In Russian).

Dal, V. I. (1978). Explanatory Dictionary of the Living Great Russian Language (In Russian).

Kuznetsova, E. B. (1989). Lexicology of the Russian language (In Russian).

Maslov, Yu. C. (1987). Introduction to linguistics (In Russian).

Maslova, V. A. (2001). Cultural linguistics (In Russian).

Myths of the peoples of the world. Encyclopedia: in 2 vols., vol. 1. (1994) (In Russian).

The New Testament of Our Lord Jesus Christ. Brussels (1989) (In Russian).

Norman, B. U. (2004). Theory of language (In Russian).

Dictionary of the poetic language (2004) (In Russian).

Ufimtseva, A. A. (1986). Lexical meaning (In Russian).

Oxford Advanced Learner's Dictionary of Current English (1982).

The New English Bible New Testament (1961). 